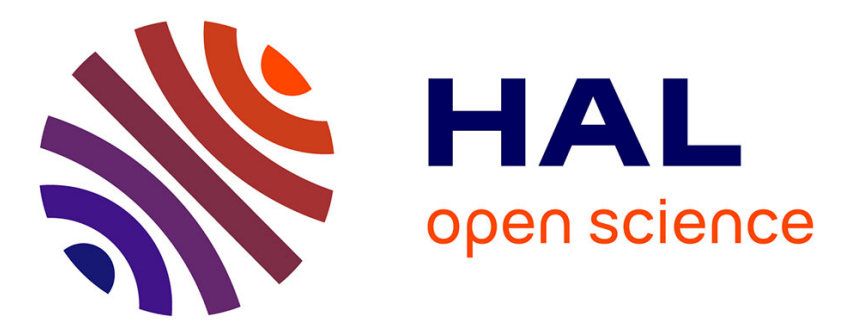

\title{
Effects of tachykinin receptor antagonists on the rat jejunal distension pain response
}

P. Mac Lean, Rafael Garcia Villar, Jean Fioramonti, Lionel Bueno

\section{To cite this version:}

P. Mac Lean, Rafael Garcia Villar, Jean Fioramonti, Lionel Bueno. Effects of tachykinin receptor antagonists on the rat jejunal distension pain response. European Journal of Pharmacology, 1998, 345 , pp.247-252. hal-02686612

\section{HAL Id: hal-02686612 \\ https://hal.inrae.fr/hal-02686612}

Submitted on 1 Jun 2020

HAL is a multi-disciplinary open access archive for the deposit and dissemination of scientific research documents, whether they are published or not. The documents may come from teaching and research institutions in France or abroad, or from public or private research centers.
L'archive ouverte pluridisciplinaire HAL, est destinée au dépôt et à la diffusion de documents scientifiques de niveau recherche, publiés ou non, émanant des établissements d'enseignement et de recherche français ou étrangers, des laboratoires publics ou privés.

\section{다(1)(2)}

Distributed under a Creative Commons Attribution - ShareAlikel 4.0 International 


\title{
Effects of tachykinin receptor antagonists on the rat jejunal distension pain response
}

\author{
Peter G. McLean, Raphael Garcia-Villar, Jean Fioramonti, Lionel Buéno * \\ Department of Pharmacology-Toxicology, INRA, 180 chemin de Tournefeuille, BP3, 31931 Toulouse, France
}

Received 11 August 1997; revised 2 January 1998; accepted 9 January 1998

\begin{abstract}
Distension of the rat intestine causes a cardiovascular response which is indicative of nociception. Since tachykinins are involved in nociception, we tested the effect of neurokinin receptor antagonists against the distension-induced response. The jejunal distension-induced depressor responses were inhibited in a dose-dependent fashion by CP 99,994 (+)-(2S,3S)-3-(2-methoxybenzylamino)-2-phenylpiperidine, tachykinin $\mathrm{NK}_{1}$ receptor antagonist, $\mathrm{ED}_{50}=0.8 \mathrm{mg} / \mathrm{kg}$ ) and $\mathrm{SR} 48968(S)$ - $N$-methyl- $N$ [4-(4-acetylamino-4phenylpiperidino)-2-(3,4-dichlorophenyl)butyl]benzamide, tachykinin $\mathrm{NK}_{2}$ receptor antagonist, $\left.\mathrm{ED}_{50}=0.7 \mathrm{mg} / \mathrm{kg}\right) . \mathrm{SR} 142801(S)-(N)$ (1-(3-(1-benzoyl-3-(3,4-dichlorophenyl)piperidin-3-yl)propyl)-4-phenylpiperidin-4-yl)- $N$-methylacetamide, tachykinin $\mathrm{NK}_{3}$ receptor antagonist, $0.3-10 \mathrm{mg} / \mathrm{kg}$ ) did not significantly affect the depressor responses to jejunal distension. In addition, CP $99,994(3 \mathrm{mg} / \mathrm{kg}$ ) and SR 48968 (3 and $10 \mathrm{mg} / \mathrm{kg}$ ) reduced sensitivity to distension as revealed by a 2.7-fold (CP 99.994, $3 \mathrm{mg} / \mathrm{kg}$ ), 2.6-fold (SR 48968, 3 $\mathrm{mg} / \mathrm{kg}$ ) and 4.7 -fold (SR 48968, $10 \mathrm{mg} / \mathrm{kg}$ ) increase in the threshold pressure. Intestinal compliance was not affected by the antagonists. In conclusion, these results suggest that tachykinin $\mathrm{NK}_{1}$ and $\mathrm{NK}_{2}$ but not $\mathrm{NK}_{3}$ receptors are possibly involved in the rat jejunal distension pain response. (C) 1998 Elsevier Science B.V.
\end{abstract}

Keywords: Tachykinin; Visceral sensation mechanism; Intestinal distension pain response; Visceral nociception; Tachykinin receptor

\section{Introduction}

Distension of the human jejunum (Bentley and Smithwick, 1940), ileum (Lipkin and Sleisenger, 1958) or colon (Swarbrick et al., 1980) is considered to be a noxious stimulus causing pressure-dependent abdominal pain. In anaesthetised rats, distension of the gastrointestinal tract produces 'pseudoaffective' reflexes (Ness and Gebhart, 1990) including a cardiovascular depressor response and bradycardia. This depressor response is considered to be indicative of visceral nociception as it is potentiated by naloxone, blocked by morphine (Ness and Gebhart, 1990) and abolished by capsaicin (Lembeck and Skofitsch, 1982). As such, the visceral distension depressor response is a useful tool in the characterisation of visceral nociception.

Only limited data are available with regard to the mechanisms and pharmacology of the visceral distension

\footnotetext{
"Corresponding author. Tcl.: +33-5-6128-5141; fax: +33-5-61285310 .
}

depressor response. $5-\mathrm{HT}_{3}$ receptor antagonists (Moss and Sanger, 1990) and opioid receptor agonists (Diop et al., 1994; Scott et al., 1997) have been shown to inhibit the response. However, cholinergic and $\alpha$-adrenergic mechanisms appear not to be involved (Lembeck and Skofitsch, 1982). The neurones involved in the mediation of the response possibly include capsaicin-sensitive peptidergic afferent fibres as the response is abolished in capsaicintreated rats (Lembeck and Skofitsch, 1982).

The involvement of capsaicin-sensitive fibres suggests that tachykinin containing nerves are involved as it is well documented that capsaicin treatment causes a depletion of tachykinins in the dorsal horn of the rat spinal cord (Gamse et al., 1980) and a degeneration of substance P containing fibres originating from the submucous ganglia (Furness et al., 1982).

Numerous reports have implicated tachykinins in the transmission of somatic nociception (e.g., Seguin et al., 1995) mediated by tachykinin $\mathrm{NK}_{1}$ and $\mathrm{NK}_{2}$ receptors. As such, tachykinins are possibly also involved in visceral 
nociception. To date, the involvement of tachykinins in the visceral distension depressor response has not been investigated. However, tachykinin $\mathrm{NK}_{1}$ and $\mathrm{NK}_{2}$ receptors have been implicated in the viscerosensitive response to rectal distension in rats (Julia et al., 1994). It has also been suggested that tachykinin $\mathrm{NK}_{3}$ receptors are involved in visceral pain (Julia and Bueno, 1995). In a preliminary report (McLean et al., 1997), it was shown that tachykinin $\mathrm{NK}_{2}$ receptors are involved in the nematode infection-induced hypersensitivity of the depressor response. Thus, the aim of the present study was to investigate the possible physiological role of tachykinins in the response by the use of the following nonpeptide, neurokinin receptor antagonists; tachykinin $\mathrm{NK}_{1}$ receptor selective: CP 99,994 (Desai et al., 1992); tachykinin $\mathrm{NK}_{2}$ receptor selective: SR 48968 (Emonds-Alt et al., 1992); and tachykinin $\mathrm{NK}_{3}$ receptor selective: SR 142801 (Emonds-Alt et al., 1995; Patacchini et al., 1995).

\section{Materials and methods}

\subsection{Surgical and experimental procedure}

Male Wistar rats weighing 300-400 g were used. The animals were deprived of food the night prior to experimentation but were given free access to water. They were anaesthetised with pentobarbitone sodium ( $60 \mathrm{mg} / \mathrm{kg}$ s.c.). Anaesthesia was maintained by re-administration of pentobarbitone sodium $(15 \mathrm{mg} / \mathrm{kg}$ per $\mathrm{h})$. Anaesthetised animals were maintained at approximately $35^{\circ} \mathrm{C}$ by placing them on a heat pad. The trachea was cannulated to prevent any airway obstruction.

A second cannula was introduced into the thoracic aorta via the left common carotid artery for constant retrograde intra-arterial infusion of saline and for further administration of anaesthetic. The rate of infusion was $40 \mu \mathrm{l} / \mathrm{min}$. Systemic blood pressure was recorded from a side-arm off the carotid cannula by means of a Statham pressure transducer (P231D) connected to a Beckman (R411 Dynograph) polygraph.

A midline incision along the length of the abdomen was made to expose the small intestine. A section of jejunum, 7 $\mathrm{cm}$ from the ligament of Treitz was used in the investigation. A cut was made at one end of the selected segment of intestine on the antimesenteric side to introduce a $5-\mathrm{cm}$ long deflated latex balloon which was loosely secured by cotton thread. The latex balloon was connected via a polyethylene catheter to a $10-\mathrm{ml}$ syringe which was connected to a second pressure transducer to record intraluminal pressure. The intestinal segment was then replaced in the peritoneal cavity and the abdomen closed.

Jejunal distension (12.5-100 $\mathrm{mmHg}, 25 \mathrm{~s}$ every $5 \mathrm{~min}$ ) has been shown to produce a stimulus-related decrease in diastolic blood pressure (Ness and Gebhart, 1990; McLean et al., 1997). The jejunum was distended by a rapid inflation of the latex balloon and the inflation volume and subsequent intraluminal pressure noted.

\subsection{Effects of neurokinin receptor antagonism}

\subsubsection{Repeated distension pressure}

The inhibitory effects of the neurokinin receptor antagonists were quantified by applying repeated distension with a submaximal, noxious intraluminal pressure of $75 \mathrm{mmHg}$ every 5 min until a constant response was achieved. In all rats, the constant response was achieved by the fourth distension and no significant differences $(P>0.05)$ were observed between any of the responses to the pre-control distensions. CP 99,994 (0.3-3 mg/kg), SR $48968(0.1-10$ $\mathrm{mg} / \mathrm{kg})$ and SR $142801(0.3-10 \mathrm{mg} / \mathrm{kg})$ or an equivalent volume of vehicle were given intraperitoneally (i.p.), intestinal distension was then recommended 10 min after drug administration and repeated at $5 \mathrm{~min}$ intervals up to 25 min following administration. The i.p. toute was chosen based on a previous study (Julia et al., 1994) in which the i.p. administration of tachykinin $\mathrm{NK}_{1}$ and $\mathrm{NK}_{2}$ receptor antagonists were shown to inhibit viscerosensitive responses to rectal distension in rats.

\subsubsection{Graded distension pressure}

Separate experiments were performed to determine threshold pressures and to investigate the effects of SR 48968 (3 and $10 \mathrm{mg} / \mathrm{kg}$, i.p.) and CP 99,994 (3 mg/kg) on the calculated threshold pressures. In these experiments, graded intestinal distension pressure $(12.5-100 \mathrm{mmHg})$-response curves were constructed in the presence of SR 48968, CP 99,994 or vehicle. Pressure-response curves were constructed 20 min after drug or vehicle administration.

All procedures were approved by the local INRA animal care and use committee.

\subsection{Data analysis}

The apparent potency of the inhibitory effect of the antagonists was quantified according to a modification of the method of Moss and Sanger (1990). Briefly, responses to repeated jejunal distension $(75 \mathrm{mmHg}$ every $5 \mathrm{~min}$ ) following antagonist administration were expressed as a percentage of the response immediately prior to dosing (taken as $100 \%$ response). The maximal effects observed over the test period were subjected to regression analysis (Graph Pad Prism, Graph Pad Software, San Diego, USA). $\mathrm{ED}_{50}$ values were calculated using linear regression analy ses from the $50 \%$ response level and expressed as the mean with $95 \%$ confidence limits (95\% C.L.). The statistical difference between the depressor responses to intestinal distension in the presence and absence of antagonists was assessed by using Student's unpaired (graded pressures) or 
Table 1

Resting mean arterial blood pressure and mean magnitude of the depressor response produced by a control distension pressure of $75 \mathrm{mmHg}$

\begin{tabular}{lll}
\hline Group & $\begin{array}{l}\text { Mean resting blood } \\
\text { pressure } \\
\text { (mmHg) }\end{array}$ & $\begin{array}{l}\text { Mean depressor } \\
\text { response } \\
\text { (mmHg) }\end{array}$ \\
\hline A vehicle & $121.1 \pm 3.1$ & $20.3 \pm 3.1$ \\
$0.3 \mathrm{mg} / \mathrm{kg}$ & $120.4 \pm 1.1$ & $28.0 \pm 3.8$ \\
$1 \mathrm{mg} / \mathrm{kg}$ & $118.5 \pm 3.1$ & $29.0 \pm 7.4$ \\
$3 \mathrm{mg} / \mathrm{kg}$ & $128.1 \pm 2.7$ & $26.3 \pm 5.0$ \\
$10 \mathrm{mg} / \mathrm{kg}$ & $129.3 \pm 2.3$ & $25.0 \pm 3.9$ \\
& & $20.3 \pm 3.1$ \\
B vehicle & $121.1 \pm 3.1$ & $31.5 \pm 4.6$ \\
$0.3 \mathrm{mg} / \mathrm{kg}$ & $125.6 \pm 2.3$ & $20.2 \pm 6.0$ \\
$1 \mathrm{mg} / \mathrm{kg}$ & $125.9 \pm 2.1$ & $26.3 \pm 5.0$ \\
$3 \mathrm{mg} / \mathrm{kg}$ & $127.0 \pm 3.5$ & $39.0 \pm 8.4$ \\
$\mathrm{C} \mathrm{vehicle}$ & $120.6 \pm 8.7$ & $26.8 \pm 5.2$ \\
$0.1 \mathrm{mg} / \mathrm{kg}$ & $129.4 \pm 2.2$ & $28.0 \pm 3.8$ \\
$0.3 \mathrm{mg} / \mathrm{kg}$ & $123.5 \pm 1.9$ & $26.1 \pm 3.0$ \\
$1 \mathrm{mg} / \mathrm{kg}$ & $122.3 \pm 2.9$ & $30.2 \pm 6.2$ \\
$3 \mathrm{mg} / \mathrm{kg}$ & $117.3 \pm 2.2$ & $21.6 \pm 3.2$ \\
$10 \mathrm{mg} / \mathrm{kg}$ & $125.6 \pm 5.2$ & \\
\hline
\end{tabular}

Values are means \pm S.E.M. of 4-8 data points for each treatment group; (A) SR 142801, (B) CP 99,994 and (C) SR 48968.

paired (repeated pressures) $t$-test. Means were considered significantly different if $P<0.05$.

The equation as described by Ness and Gebhart (1988):

$(\text { A blood pressure })^{2}=($ slope $\times$ distension $)+$ intercept

allowed a transformation of the graded pressure-response function. The distension threshold represented the calculated distension value that would evoke a measurable change in diastolic blood pressure of $10 \mathrm{mmHg}$.

Intestinal pressure-volume curves were constructed as a measure of intestinal compliance according to the methods described by Gregersen and Kassab (1996) to determine whether changes in intestinal compliance occurred following antagonist administration. Intestinal compliance was calculated from the slope of the linear portion of the intestinal pressure-volume curves.

\subsection{Drugs}

CP $99.994(+)-(2 S, 3 S)-3-(2-m e t h o x y b e n z y l a m i n o)-2-$ phenylpiperidine), SR 48968 ( $S)$ - $N$-methyl- $N$ [4-(4-acetylamino-4-phenylpiperidino)-2-(3,4-dichIorophenyl)butyl]benzamide) and $\mathrm{SR} 142801,(S)$ $(N)$-(1-(3-(1-benzoyl-3-(3,4-dichlorophenyl)piperidin-3-yl) propyl)-4-phenylpiperidin-4-yl)- $N$-methylacetamide were dissolved in dimethylsulfoxide (DMSO) and made up to volume with an equivalent volume of $0.9 \%$ saline. The 'SR' compounds were kindly supplied by Dr. Emonds-Alt, Sanofi Laboratories (Montpellier, France) and CP 99,994 from Dr. Kadin, Central Pfizzer (Groton, CT, USA).

\section{Results}

\subsection{Effects of jejunal distension}

Jejunal distension $(12.5-100 \mathrm{mmHg}, 25 \mathrm{~s}$ every $5 \mathrm{~min})$ elicited a rapid pressure-dependent decrease in diastolic blood pressure (see Fig. 3) in $85 \%$ of rats. The data from nonresponding rats were not included.

\subsection{Effects of neurokinin receptor antagonists on the depressor response to jejunal distension}

Intraperitoneal administration of the DMSO/saline vehicle $(0.6 \mathrm{ml} / \mathrm{kg}), \mathrm{CP} 99,994(0.3-3 \mathrm{mg} / \mathrm{kg}, n=13)$, SR $48968(0.1-10 \mathrm{mg} / \mathrm{kg}, n=27)$ and SR $142801(1-10$ $\mathrm{mg} / \mathrm{kg}, n=21$ ) had no significant sustained effect on resting blood pressure.

\subsubsection{Repeated distension pressure}

Table 1 shows the resting mean arterial blood pressures and the magnitude of the depressor responses produced by the control, $75 \mathrm{mmHg}$ distension pressure in each treatment group. No significant difference $(P>0.05)$ was ob-

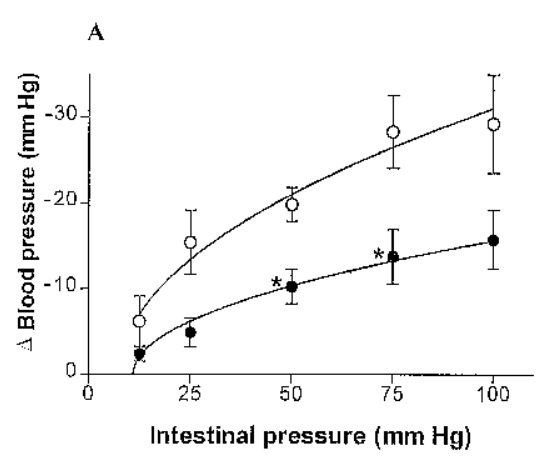

B

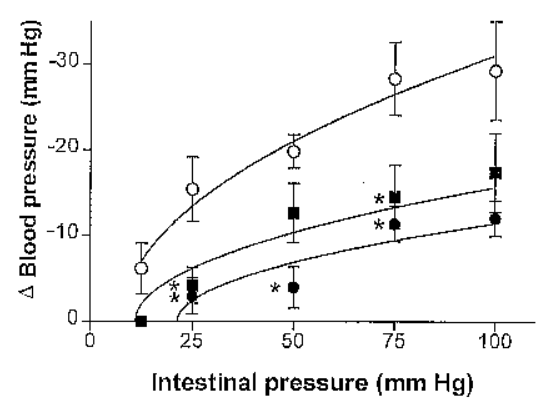

Fig. 1. Regression analyses of the fall in blood pressure induced by graded jejunal distension pressures $(12.5-100 \mathrm{mmHg}, 25 \mathrm{~s}$ every $5 \mathrm{~min})$. Data obtained in the absence $(O, n=5)$, or presence of (A) CP 99,994 (3 $\mathrm{mg} / \mathrm{kg}, \quad, n=4$ ) or (B) SR 48968 ( $3 \mathrm{mg} / \mathrm{kg}, \mathbf{\square}, n=4 ; 10 \mathrm{mg} / \mathrm{kg}$, $n=4$ ). Each point represents the mean \pm S.E.M. $* P>0.05$, unpaired $t$-test. Regression analyses have the equations: control, $y^{2}=10.4 x-81$; CP 99,994 (3 mg $/ \mathrm{kg}), y^{2}=2.7 x-30:$ SR $48968(3 \mathrm{mg} / \mathrm{kg}), y^{2}=4.4 x$ $-87 ;(10 \mathrm{mg} / \mathrm{kg}), y^{2}=1.7 x-35$. 

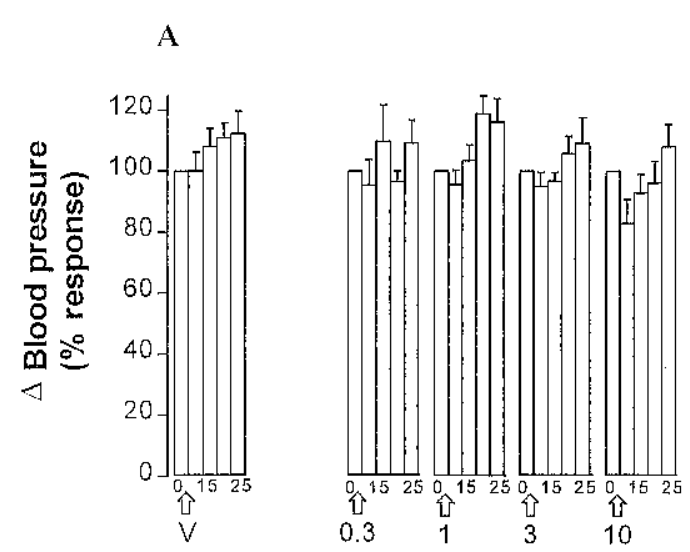

Time (min) SR 142801
$(\mathrm{mg} / \mathrm{kg})$

B
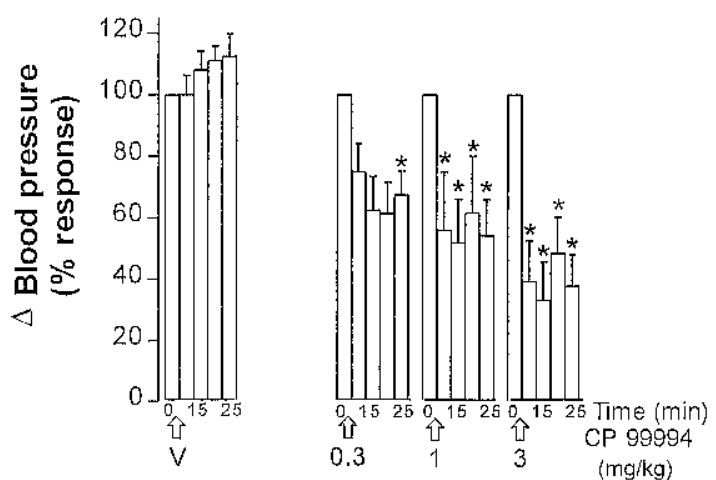

C

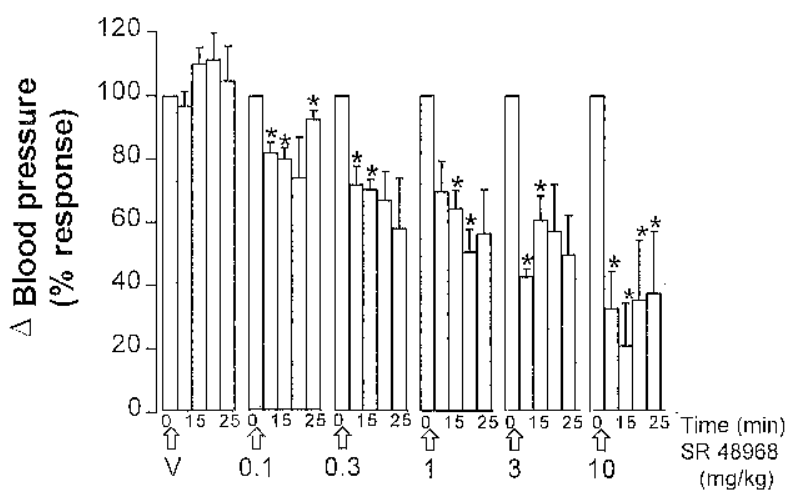

Fig. 2. Effects of (A) SR $142801(0.3-10 \mathrm{mg} / \mathrm{kg}$ i.p.). (B) CP 99,994 $(0.3-3 \mathrm{mg} / \mathrm{kg}$ i.p.) and (C) SR $48968(0.1-10 \mathrm{mg} / \mathrm{kg}$ i.p. $)$ or vehicle $(V=0.9 \%$ saline:dimethylsulfoxide; $50: 50, \mathrm{v} / \mathrm{v})$ administered after a control distension $(\Uparrow)$ on the fall in blood pressure induced by repeated jejunal distension pressures $(75 \mathrm{mmHg}, 25 \mathrm{~s}$ every $5 \mathrm{~min}$ ). The first column in each group represents the pre-dose control response taken as $100 \%$. Each column represents the mean \pm S.E.M. of $4-8$ data points. $* P<0.05$, paired $t$-test.

served between the depressor responses in any of the groups. The i.p. administration of the tachykinin $\mathrm{NK}_{1}$ receptor antagonist $\mathrm{CP} 99,994(0.3-3 \mathrm{mg} / \mathrm{kg})$ and the tachykinin $\mathrm{NK}_{2}$ receptor antagonist SR $48968(0.1-10$ $\mathrm{mg} / \mathrm{kg}$ ) produced dose-dependent inhibition of these depressor responses (Fig. 1B,C) giving rise to $\mathrm{ED}_{50}$ values of $0.8 \mathrm{mg} / \mathrm{kg}(95 \%$ C.L., $0.1-6.1, n=11)$ and $0.7 \mathrm{mg} / \mathrm{kg}$ (95\% C.L., 0.4-1.5, $n=19$ ), respectively (Fig. 2).

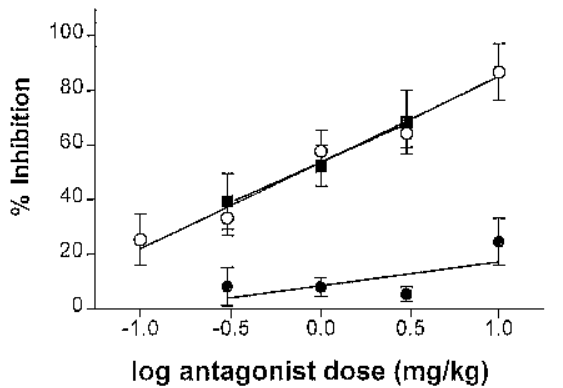

Fig. 3. Linear regression analysis of the effects of CP 99,994 (0.3-3 $\mathrm{mg} / \mathrm{kg}, \mathbf{\square}, n=11), \mathrm{SR} 48968(0.1-10 \mathrm{mg} / \mathrm{kg}, \mathrm{O}, n=19)$ and $\mathrm{SR}$ $142801(0.3-10 \mathrm{mg} / \mathrm{kg}, \bigcirc, n=21)$ on the fall in blood pressure induced by repeated jejunal distension pressure $(75 \mathrm{mmHg}, 25 \mathrm{~s}$ every $5 \mathrm{~min}$ ). The effects of the antagonists are plotted as the percentage inhibition of the response immediately prior to dosing. Each point represents the mean \pm S.E.M. of 4-7 data points.

There was no statistically significant effect of the tachykinin $\mathrm{NK}_{3}$ receptor antagonist SR 142801 (0.3-10 $\mathrm{mg} / \mathrm{kg}, n=21$ ) on the responses to jejunal distension at any of the doses tested (Fig. 1A). However, a trend towards inhibition was observed at the highest concentration of $10 \mathrm{mg} / \mathrm{kg}$ (Fig. 1A and Fig, 2).

In all repeated distension pressure experiments, the administration of each of the antagonists, at all doses tested, did not significantly affect the volume of air required $(3.0-3.2 \mathrm{ml})$ to induce a constant intestinal pressure of $75 \mathrm{mmHg}$.

\subsubsection{Graded distension pressure}

In separate experiments, graded jejunal distension pressures $(12.5-100 \mathrm{mmHg}, 25 \mathrm{~s}$ every $5 \mathrm{~min})$ elicited pressure-dependent depressor responses (Fig. 3). These experiments were designed to investigate the effects of $\mathrm{CP}$ 99,994 and SR 48968 on threshold pressures and, hence, intestinal sensitivity. The resting mean arterial pressures from these experiments was $121 \pm 1.2 \mathrm{mmHg}(n=17)$.

Following CP 99,994 (3 mg/kg, i.p.) or SR 48968 (3 and $10 \mathrm{mg} / \mathrm{kg}$, i.p.) administration depressor responses to jejunal distension were significantly reduced relative to

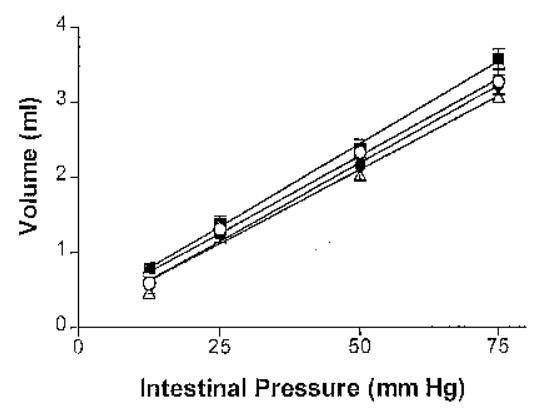

Fig. 4. Intestinal compliance detcrmination over the pressure range $12.5-75 \mathrm{mmHg}$ in the absence $(\mathrm{O}, n=5)$ or presence of $\mathrm{CP} 99,994,3$ $\mathrm{mg} / \mathrm{kg}(\Delta, n=4), \mathrm{SR} 48968,3 \mathrm{mg} / \mathrm{kg}(\boldsymbol{O}, n=4)$ and $10 \mathrm{mg} / \mathrm{kg}(\mathbf{\square}$, $n=4$ ). (compliance $=0.04 \pm 0.002)$ (control, CP 99,994 $(3 \mathrm{mg} / \mathrm{kg})$ and SR $48968(10 \mathrm{mg} / \mathrm{kg}$ ) and $0.04 \pm 0.005$ (SR $48968,3 \mathrm{mg} / \mathrm{kg}$ ) volume in $\mathrm{ml} / \mathrm{mm} \mathrm{Hg}, P>0.05)$. 
vehicle controls $(n=5)$ and a 2.7 -fold (CP 99,994, 3 $\mathrm{mg} / \mathrm{kg}, n=4$ ), 2.6-fold (SR 48968, $3 \mathrm{mg} / \mathrm{kg}, n=4$ ) and 4.7-fold (SR $48968,10 \mathrm{mg} / \mathrm{kg}, n=4$ ) increase in threshold pressure was observed (Fig. 3) increasing from 17.4 $\mathrm{mmHg}$ (control, $n=5$ ) to $47.4 \mathrm{mmHg}$ (CP 99,994, 3 $\mathrm{mg} / \mathrm{kg}, n=4), 44.6 \mathrm{mmHg}$ (SR $48968,3 \mathrm{mg} / \mathrm{kg}, n=4)$ and $81.7 \mathrm{mmHg}$ (SR $48968,10 \mathrm{mg} / \mathrm{kg}, n=4)$.

Intestinal pressure-volume curves were constructed as a measure of intestinal compliance (Fig. 4). The curves were significantly linear over the pressure range and compliance values following the administration of $\mathrm{CP}$ 99,994 (3 $\mathrm{mg} / \mathrm{kg}$ ) and SR 48968 (3 and $10 \mathrm{mg} / \mathrm{kg}$ ) were not significantly different to vehicle controls $(P>0.05$, Fig. 4).

\section{Discussion}

Distension of the gastrointestinal tract elicits visceral pain in man (Prochacci et al., 1979) and increased visceral perception of distension or motility of digestive organs has been described in patients with functional bowel disorders (Kellow et al., 1991; Mayer and Raybould, 1990). The present study has added to the knowledge of visceral sensation mechanisms via an investigation into the involvement of neurokinin receptors in the rat jejunal distension pain response.

The data obtained with the tachykinin $\mathrm{NK}_{1}$ receptor selective antagonist, CP 99,994 in the present study suggests an involvement of tachykinin $\mathrm{NK}_{1}$ receptors in the response. The involvement of tachykinin $\mathrm{NK}_{1}$ receptors in visceral nociception is supported by other studies in which viscero-visceral reflexes were inhibited by tachykinin $\mathrm{NK}_{\mathrm{I}}$ receptor antagonism (Julia et al., 1994). The apparent potency of CP 99,994 in the present study $\left(\mathrm{ED}_{50}=0.8\right.$ $\mathrm{mg} / \mathrm{kg}$ ) indicates an activity on tachykinin $\mathrm{NK}_{1}$ receptors as it is in line with its in vivo potency in other studies such as in guinea pig ( $1 \mathrm{mg} / \mathrm{kg}$, Foulon et al., 1993; 1-3 $\mathrm{mg} / \mathrm{kg}$, Rupniak and Jackson, 1994), ferret $(0.3-3 \mathrm{mg} / \mathrm{kg}$, Tattersall et al., 1993, 1994), rat $(1.8 \mathrm{mg} / \mathrm{kg})$ and mouse (1.1 $\mathrm{mg} / \mathrm{kg}$ ). Thus, if differences exist between the potency of CP 99,994 at rat tachykinin $\mathrm{NK}_{1}$ receptors and other species as suggested previously (Beresford et al., 1991; McLean et al., 1993), the present study shows that they are not discriminated by the visceral distension depressor response in the anaesthetised rat.

The data obtained with the tachykinin $\mathrm{NK}_{2}$ receptor antagonist SR 48968 (Emonds-Alt et al., 1992) is also in line with previous studies in which tachykinin $\mathrm{NK}_{2}$ receptor antagonists have been shown to have antinociceptive properties against somatic pain (e.g., Seguin et al., 1995). The apparent in vivo potency of SR 48968 determined in the present study $\left(\mathrm{ED}_{50}=0.7 \mathrm{mg} / \mathrm{kg}\right)$ correlates well with its potency against other tachykinin $\mathrm{NK}_{2}$ receptor-mediated responses in the anaesthetised rat $(0.5 \mathrm{mg} / \mathrm{kg}$, i.v.; Santucci et al., 1993); the conscious guinea pig $(0.1 \mathrm{mg} / \mathrm{kg}$, i.p.; Advenier et al., 1993) and in mice $(0.15 \mathrm{mg} / \mathrm{kg}$, i.p.;
Poncelet et al., 1993). In another study, Julia et al. (1994) showed that a dose of $5 \mathrm{mg} / \mathrm{kg}$ of SR 48968 was submaximal against the viscerosensitive response to rectal distension in rats.

The lack of activity of the tachykinin $\mathrm{NK}_{3}$ receptor antagonist SR 142801 at concentrations which have been shown to be active in vivo in other studies (Emonds-Alt et al., 1995; Patacchini et al., 1995) suggests that tachykinin $\mathrm{NK}_{3}$ receptors are not involved in the rat visceral distension depressor response. However, this could also be explained by the observation by Emonds-Alt et al. (1995) that SR 142801 possesses a reduced potency at rat tachykinin $\mathrm{NK}_{3}$ receptors compared to other species.

Intestinal compliance and therefore the degree of stretch (which is the stimulus to visceral mechanoreceptors (Gregersen and Kassab, 1996) induced by distension was not affected by the antagonists. As such, the inhibitory effects observed can not be attributed to changes in intestinal compliance and are most likely to result from an effect on the pathway mediating the depressor response.

In summary, this study has shown that CP 99,994 and SR 48968 inhibit the jejunal distension-induced pain depressor response in rats, thus, suggesting an involvement of tachykinins, acting via tachykinin $\mathrm{NK}_{1}$ and $\mathrm{NK}_{2}$ receptors, respectively, in the perception of noxious visceral stimuli. These findings are possibly relevant to functional bowel disorders in which altered pain perception can result from visceral hypersensitivity. The lack of activity of SR 142801 suggests either that tachykinin $\mathrm{NK}_{3}$ receptors are not involved in the response or that SR 142801, at the concentrations tested, was not active against rat tachykinin $\mathrm{NK}_{3}$ receptors.

\section{Acknowledgements}

PM is an INRA research fellow and the work was funded by INRA, France.

\section{References}

Advenier, C., Girard, V., Naline, E., Vilain, P., Emonds-Alt, X., 1993 Antitussive effect of SR 48968, a nonpeptide tachykinin $\mathrm{NK}_{2}$ receptor antagonist. Eur. J. Pharmacol. 250, 169-171.

Bentley, F.H., Smithwick, R.H., 1940. Visceral pain produced by balloon distension of the jejuntm. Lancet i-ii, 389-391.

Beresford, 1.J.M., Birch, P.J., Hagan, R.M., Ireland, S.J., 1991. Investiga-

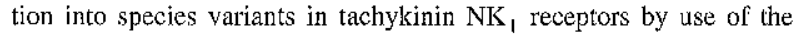
nonpeptide antagonist CP-96345. Br. J. Pharmacol. 104, 292-293.

Desai, M.C., Lefkowitz, S.L., Thadeio, P.F., Longo, K.P., Snider, R.M., 1992. Discovery of a potent substance $P$ antagonist: recognition of the key molecular determinant. J. Med. Chem. 35, 4911-4913.

Diop, L., Riviere, P.J., Pascaud, X., Junien, J.L., 1994. Peripheral kappaopioid receptors mediate the antinociceptive effect of fedotozinc on the duodenal pain reflex in rat. Eur. J. Pharmacol. 271, 65-71.

Emonds-Alt, X., Vilain, P., Goulaouic, P., Proietto, V., Van Brocek, D., Advenier, C., Naline, E., Neliat, G., Le Fur, G., Breliere, J.C., 1992. $\mathrm{A}$ potent and selective nonpeptide antagonist of the neurokinin $\mathrm{A}$ $\left(\mathrm{NK}_{2}\right)$ receptor. Life Sci. 50, PL101-106. 
Emonds-Alt, X., Bichon, D., Ducoux, J.P., Heaulme, M., Miloux, B., Poncelet, M., Proietto, V., Van Broeck, D., Viłain, P., Neliat, G., 1995. SR 142801, the first potent nonpeptide antagonist of the tachykinin $\mathrm{NK}_{3}$ receptor. Life Sci. 56, PL27-32.

Foulon, D.M., Champion, E., Masson, P., Rodger, I.W., Jones, T.R., 1993. $\mathrm{NK}_{1}$ and $\mathrm{NK}_{2}$ receptors mediate tachykinin and resiniferatoxin-induced bronchospasm in guinea pigs. Am. Rev. Respir. Dis. $148,915-921$

Furness, J.B., Papka, R.E., Della, N.G., Costa, M., Eskay, R.L., 1982. Substance P-like immunoreactivity in nerves associated with the vascular system of guinea pigs. Neuroscience 7, 447-459.

Gamse, R., Holzer, P., Lembeck, F., 1980. Decrease of substance P in primary afferent neurones and impairment of neurogenic plasma extravasation by capsaicin. Br. J. Pharmacol, 68, 207-213.

Gregersen, H., Kassab, G., 1996. Biomechanics of the gastrointestinal tract. Neurogastroenterol. Motil. 8, 277-297.

Julia, V., Bueno, L., 1995. Central and peripheral $\mathrm{NK}_{3}$ receptors mediated antinociception and nociception respectively in response to rectal distension in rats. Neurogastroenterol. Mot, 7, 133-133.

Julia, V., Morteau, O., Bueno, L., 1994. Involvement of neurokinin 1 and 2 receptors in viscerosensitive response to rectal distension in rats. Gastroenterology 107, 94-102.

Kellow, J.E., Eckersley, C.M., Jones, M.P., 1991. Enhanced perception of physiological intestinal motility in the irritable bowel syndrome. Gastroenterology 101, 1621-1627.

Lembeck, F., Skofitsch, G., 1982. Visceral pain reflex after pretreatment with capsaicin and morphine. Naunyn Schmied. Arch. Pharmacol. $321,116-122$.

Lipkin, M., Sleisenger, M.H., 1958. Studies of visceral pain: measurements of stimulus intensity and duration associated with the onset of pain in oesophagus, ileum and colon. J. Clin. Invest. 37, 28-34.

Mayer, E.A., RaybouId, H.E., 1990. Role of visceral afferent mechanisms in functional bowel disorders. Gastroenterology 99, 1688-1704.

McLean, S., Ganong, A., Seymour, P.A., Snider, R.M., Desai, M.C., Rosen, T., Bryce, D.K., Longo, K.P., Reynolds, L.S., Robinson, G., 1993. Pharmacology of CP 99,994 ; a nonpeptide antagonist of the tachykinin neurokinin 1 receptor. J. Pharmacol. Exp. Ther. 267, $472-479$.

McLean, P.G., Picard, C., Garcia-Villar, R., Moré, J., Fioramonti, J., Buéno, L., 1997. Effects of nematode infection on sensitivity to intestinal distension: role of $\mathrm{NK}_{2}$ receptors. Eur. J. Pharmacol. 337, $279-282$.
Moss, H.E., Sanger, G.J., 1990. The effects of granisetron. ICS 205-930 and ondansetron on the visceral pain reflex induced by duodenal distension. Br. J. Pharmacol. 100, 497-501.

Ness, T.J., Gebhart, G.F., 1988. Colorectal distension as a noxious visceral stimulus: physiologic and pharmacologic characterization of pseudoaffective reflexes in the rat. Brain Res. 450, 153-169.

Ness, T.J., Gebhart, G.F., 1990. Visceral pain: a review of experimental studies. Pain 41, 167-234.

Patacchini, R., Bartho, L., Holzer, P., Maggi, C.A., 1995. Activity of SR 142801 at peripheral tachykinin receptors. Bur. J. Pharmacol. 278, $17-25$.

Poncelet, M., Gucudet, C., Emonds-Alt, X., Breliere, J.C., Le Fur, G., Soubrie, P., 1993. Turning behavior induced in mice by a neurokinin A receptor agonist: stereoselective blockade by SR 48968, a nonpeptide receptor antagonist. Neurosci, Lett. 149, 40-42.

Prochacci, P., Zoppi, M., Maresca, M., 1979. Experimental pain in man. Pain 6, 123-140.

Rupniak, N.M., Jackson, A., 1994. Nonspecific inhibition of dopamine receptor agonist-induced behavior by the tachykinin $\mathrm{NK}_{\text {, receptor }}$ antagonist CP 99,994 in guinea pigs. Eur. J. Pharmacol. 262, 171-175.

Santucci, V., Gucudet, C., Edmonds-Alt, X., Breliere, J.C., Soubrie, P., Le Fur, G., 1993. The $\mathrm{NK}_{2}$ receptor antagonist SR 48968 inhibits thalamic responses evoked by thermal but not mechanical nociception. Eur, J. Pharmacol. 237, 143-146.

Scott, C.M., Smith, G., Bountra, C., 1997. The differential effects of fentanyl on dorsal horn neurones responsive to colorectal distension within the lumbosacral cord of the anaesthetised rat. Br. J. Pharmacol. $120,221 P$.

Seguin, L., Le Marouille-Girardon, S., Millan, M.J., 1995. Antinociceptive profiles of nonpeptidergic neurokinin 1 and neurokinin 2 receptor antagonists: a comparison to other classes of antinociceptive agent. Pain 61, 325-343.

Swarbrick, E.T., Bat, L., Hegarty, J.E., Williams, C.B., Dawson, A.M., 1980. Site of pain from the irritable bowel. Lancet ii, 443-446.

Tattersall, F.D., Rycroft, W., Hargreaves, R.J., Hill, R.G., 1993. The

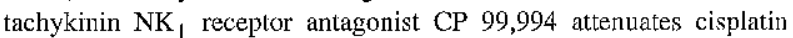
induced emesis in the ferret. Eur. J. Pharmacol. 250, R5-R6.

Tattersall, F.D., Rycroft, W., Hill, R.G., Hargreaves, R.J., 1994. Enantioselective inhibition of apomorphine-induced emesis in the ferret by the neurokinin 1 receptor antagonist CP 99,994. Neuropharmacology $33,259-260$. 

. 